LIBRES: Library and Information Science Research

Electronic Journal ISSN 1058-6768

2001 Volume 11 Issue 1; March 31

Bi-annual LIBRES 11N1

\title{
Rough Seas and the Journal of Academic Librarianship: Differing Opinions by Two Academic Librarians
}

\author{
OPINION \#1: ROW STRAIGHT AHEAD \\ by Steve McKinzie \\ Social Science Liaison, Dickinson College \\ Carlisle, Pennsylvania, USA
}

When navigating the seas of collection development, you sometimes have to cover your ears to the sirens' cries from the shore, row straight ahead, and let nothing distract you. It is very much like that now, if you find yourself listening to the shore pleas of some of the profession's most distinguished voices. The sirens, such as Ray English of Oberlin College and Sue Martin of Georgetown University, are urging librarians to cancel their subscription to one of the library profession's flagship journals, The Journal of Academic Librarianship. The journal has new owners, Elsevier Publishers, and the sirens implore libraries to drop their subscription and add in its place a soon-to-be-published alternative, Portal: Libraries and the Academy. Librarians, they argue, should set an example to their academic colleagues by being willing to cancel overpriced Elsevier titles in their own academic field of librarianship.

The arguments of English and Martin are straightforward enough. They are generally persuasive, but they are largely wrong. According to the profession's established guidelines of collection development, libraries should retain their subscriptions to The Journal of Academic Librarianship. Never mind who publishes it.

The flap over subscriptions began in May, 1999, when the noted science publisher Elsevier purchased the publishers of The Journal of Academic Librarianship. A large contingent of the editorial staff resigned at that point and subscription costs to the journal went up almost immediately, an increase that, according to Elsevier's critics, was as unjustified as it was expected. The increase reflected what the critics believed was a general tendency of Elsevier - to prey upon libraries, charging whatever the market will bear, knowing full well that libraries can ill afford to cancel major academic titles.

In the wake of the $J A L$ takeover, some of the editorial staff who resigned began plans to launch an experimental rival publication - the earlier mentioned and tentatively titled Portal: Libraries and the Academy. The new title promises to compete with the old, 
and it will come at a lower cost, being largely a not-for-profit venture under the auspices of Johns Hopkins University Press and the talented leadership of Susan K. Martin. Martin describes the new journal effort as an "alternative - one that will allow academic librarians to publish in and subscribe to a vehicle that contains materials of interest, utility and substance, without paying exorbitant prices." ${ }^{[1]}$ Ray English, Oberlin College's Library Director, has recently encouraged his numerous colleagues in the Oberlin Library Director's Group to discontinue $J A L$ and add in its place the upstart, Portal: Libraries and the Academy.

While I applaud the tenacity of the Sue Martin, commend Ray English's temerity to arrest spiraling journal costs, and agree that most journals cost more than they should, I reject the implication and/or assertion that libraries should cancel Journal of Academic Librarianship. Such a decision isn't good collection management, and it isn't good sense.

Library journal collection policy follows specified guidelines. In academic libraries, journal collection development supports the curriculum. Or to put it another way, journal collections must meet the information needs of a given research community. This is true in library and information science, as it is in other fields, although an academic library's journal collection often has the secondary responsibility of also serving the professional information needs of library professionals and staff.

In either case, libraries build journal collections around patron needs, with an eye both for economy and quality. Journal costs have to be kept low, because inflated costs can prohibit the purchase of other materials, but libraries also have a responsibility to buy the best possible titles for their collection. It is simply a case of buying the highest quality periodicals possible within a given budget. That is why efforts like SPARC (Scholarly Publishing and Academic Resource Consortium) or leverage buying efforts deserve praise and support.

Even so, the premature canceling of The Journal of Academic Librarianship at this juncture in its history makes little sense. It runs counter to sound collection development policy, which dictates that libraries must do everything they can to purchase the best quality journals in a given academic field.

It may be that with time, the new Portal: Libraries and the Academy will replace the Journal of Academic Librarianship. The newer title may in time out class the older $J A L$. This is obviously Martin's wish when she writes that, "I hope that the spirit and quality that have been the hallmarks of $J A L$ in the last twenty-five years since its birth will continue, albeit with another name."

But in the meantime, prudence demands caution. By almost all accounts and by almost anybody's standard, The Journal of Academic Librarianship is one of the two top journals in the field of library and information science. It is the kind of journal that constitutes, aside from its recent controversies, an almost sine quo non of the discipline's periodical collection. In a 1998 article, Mickey Zemon and Alice Harrison Bahr call both $J A L$ and College and Research Libraries "by common consensus ... the major journals in 
academic librarianship," while Gregory A. Crawford said simply and categorically in 1999 that JAL and College and Research Libraries "are the two primary journals in the field of academic librarianship."

In addition to the journal's high level of prestige and respect that it seems to share with only one other journal in the discipline, $J A L$ has more than twenty-five years of publishing excellence at its back. Concomitant with that experience, the journal has been able to preserve a goodly number of its acting editors. Especially important in this regard, the journal retains its senior editor at the helm, Peter Hernon, an individual whose integrity and drive have largely been responsible for the journal's sustained success.

All of this points to the nearly incontestable fact that The Journal of Academic Librarianship will likely maintain a large measure of its quality and prestige in the coming years. It's true that a subscription to The Journal of Academic Librarianship will probably cost more in the future. There is no reason to make any bones about that. It won't be as inexpensive as some of us would like it to be, but it won't be unreasonable either. A subscription will, nevertheless, guarantee library users access to a journal that will likely continue to lead its field.

My advice to librarians is simple. Buy the best journals for your library and don't fret over the publishers. Ignore the well-meaning siren songs from distinguished librarians who want us to boycott titles or build our collections around publishers instead of around the journals themselves. Such counsel is persuasive, but it misleads. Row straight ahead.

\section{Footnotes}

1. Susan K. Martin, "When Vision Encounters Reality: A Professional Dilemma," Journal of Academic Librarianship 25, no.3 (May 1999): 223.

2. Ibid.

3. Mickey Zemon and Alice Harrison Bahr, "An Analysis of Articles by College Librarians, College and Research Libraries 59, no. 5 (September 1998): 424, and Gregory A. Crawford, "The Research Literature of Academic Librarianship," College and Research Libraries 60, no. 3 (May 1999): 224.

\section{OPINION \#2: CHANGE COURSE}

by Jocelyn Godolphin

Head, Humanities and Social Sciences, Koerner Library

The University of British Columbia

Vancouver, B.C., Canada

jgodol@interchange.ubc.ca

Mr. McKinzie encourages us to row straight ahead and avoid the siren calls from the shore that would encourage us to cancel the Journal of Academic Librarianship since it has been bought by Elsevier. I fear that Mr McKinzie, in his own earnest rowing straight ahead, has not realized that the tide has turned. He is at great risk of being swamped, if he 
does not rethink the direction his argument is taking him. The turning of the tide was evidenced sometime ago in the appearance of initiatives like SPARC, which demonstrate that libraries can help change scholarly publishing.

By advocating the simple principle of buy the best and hang the cost, Mr. McKinzie encourages the continuance of the status quo. Commercial publishers apply pricing models that don't reflect the actual costs of production, because their customers, the libraries, respond to the demands of users who, free from knowledge of budget constraints and subscription costs, lobby the library to include the more and more specialized journals of their fields, which report the research that has usually been funded by the same pocket as supports both research and library.

Mr. McKinzie acknowledges that "efforts like SPARC or leverage buying efforts deserve praise and support," but does not recognize that these initiatives occurred because librarians were willing to encourage the scholarly community to reassert ownership of its information. As evidence, see. "SPARC Influence Cited as Wiley Cuts Journal Price" at http://www.createchange.org.

Like most other academic collection development librarians, I have had to oversee rounds of serial cancellations, all involving negotiations with faculty over which journals to keep and which to cancel. I could not look the faculty straight in the eye, if, in my own field, I insisted on subscribing to $J A L$, regardless of cost. Mr. McKinzie's argument is familiar: I have heard it many times from faculty who were insistent that their journals must be maintained by the library, regardless of the risk to a balanced collection.

The advocates of canceling $J A L$ are not reacting purely to price increases. They are saying that librarians must show leadership in the scholarly publishing of their own field, and declare their unease with for-profit multinationals increasing their monopoly on scholarly information. We must row in a better direction towards creating new systems of distributing scholarly information. No doubt, the way is dangerous, and there are shoals ahead, but at least we are taking action to reassert the scholarly community's ownership of its own communication system.

This document may be circulated freely with the following statement included in its entirety:

Copyright 2001

This article was originally published in

LIBRES: Library and Information Science

Electronic Journal (ISSN 1058-6768) March 31, 2001

Volume 11 Issue 1.

For any commercial use, or publication

(including electronic journals), you must obtain

the permission of the authors. 
Steve McKinzie

Social Science Liaison, Dickinson College

Carlisle, Pennsylvania, USA

by Jocelyn Godolphin

Head, Humanities and Social Sciences, Koerner Library

The University of British Columbia

Vancouver, B.C., Canada

jgodol@interchange.ubc.ca

To subscribe to LIBRES send e-mail message to

listproc@info.curtin.edu.au

with the text:

subscribe libres [your first name] [your last name]

Return to Libres 11n1 Contents

Return to Libres Home Page

CRICOS provider code: 00301J 